\title{
A Comparative Analysis of the Past and the Present: Plateau Settlements and Semi-Nomadic Life in the Taurus Mountains (Turkey)
}

\author{
By Kemal Reha Kavas ${ }^{*}$ \\ Ibrahim Bakır
}

This paper makes a comparative analysis of the past and present situation of the "plateaus" and "semi-nomadic life" in the Taurus Mountains of Southern Turkey. The main objective is to understand the concepts of "plateau" and "semi-nomadism" in their historical context, to make a spatial and historical analysis of these concepts, to compare the past and the present spatial approaches in the plateaus and to understand the transformations of the semi-nomadic societies. In order to reach this goal, this study unfolds the traditional semi-nomadic spatial configurations developed for living in the plateaus and sustaining environmental harmony. The contemporary spatial developments in the plateaus are also investigated by referring to the transformations that have occurred in the semi-nomad soceities. The study identifies the main differences between the past and the present situation of the plateaus in terms of spatial configurations. It is seen that, although the past culture was harmonious with environment the present situation violates this harmony. By analyzing the harmony between the semi-nomadic patterns of space and natural environment, further proposals can be derived as guidelines for future planning.

Keywords: Mediterranean, plateau, semi-nomad, settlement, Taurus, Yörük

\section{Introduction}

Nomadic societies have had profound effects on the cultural history of Anatolia, Mediterranean Basin and Eurasia (Chailand and Berrett 2004: 2-8). In this geography, due to shortage of pastures and water, seasonal change of habitat has been an obligation. As a result nomadic life and its architectural configurations have developed over time (Braudel 2002: 161-162). Through their long distanced and massive movements, nomadic tribes have become the reason for important political transformations. In contrast to the long distanced nomadic movements with a military nature, there has been another version of non-military nomadism developed in the Mediterranean basin. In Western resources this type of nomadism is called "transhumance". This is a type of seasonal oscillation within defined regional limits and between the coast and mountains (Totani 2008). Transhumance movements follow exactly the same routes every year and it is kept within predefined borders (Tanyeli 1996).

\footnotetext{
*Associate Professor, Akdeniz University Faculty of Fine Arts, Department of Architecture, Antalya - Turkey. kemalkavas@akdeniz.edu.tr

${ }^{\dagger}$ Assistant Professor, Akdeniz University Faculty of Fine Arts, Department of Architecture, Turkey.
} 
Transhumance does not signify tribes wandering around space with continuous movement all the year long. It has a semi-nomadic nature because in this pattern of life there are points of habitation where the tribes settle for certain time periods. Transhumant (semi-nomadic) tribes move through defined routes and stop at locations with environmental resources.

For example, semi-nomadic tribes of Western Taurus Mountains in Southwestern Turkey have permanent dwellings for winter use but they leave their dwellings and start to change locations during the summer time. During the summer they prefer higher altitudes with refreshing weather and sufficient pastures for their animals and continue living in temporary, flexible, demountable and lightweight shelters adapted to this lifestyle. Plateau (yayla), which is the main subject of this paper, is the place for temporary habitation in summer. Plateaus are distinguished places between the Taurus Mountains, where pastures and water resources are abundant (Seyirci, 2000, p. 100). They are usually places of higher altitude with cool and fresh air during the summer season.

This study tries to understand the concepts of "plateau" and "seminomadism" in their historical context. By this way it becomes possible to make a spatial analysis of the historical and contemporary states of these concepts, to compare the past and the present approaches in the configuration of space in the plateaus and to understand the transformations of the plateaus and the seminomadic societies. As a result this study aims to answer the following questions: Which spatial configurations and strategies were developed by the semi-nomads in order to sustain an enduring culture in this difficult geography? What are the contemporary situations of the plateaus and seminomads? Which spatial principles can be derived by making this comparison between the past and the present of this society?

\section{Materials and Methods}

\section{Research Material}

The main research material of this study is the semi-nomadic culture of Anatolia and its spatial configurations in the past and the present. In order to understand the defining features of the material, the historical origins and original spatial qualities of this culture should be analyzed.

It is argued that Anatolian semi-nomadism is strongly affected by Central Asian traditions. Semi-nomadic life forms appeared in Altay and Tanri Mountains around $1700 \mathrm{BC}$ and these traditions were adapted and sustained by the Hun (300 BC - 300 AD) and Gokturk (300 - 600 AD) administrations (Ögel, 1991). After the Gokturk State, as the human and animal population of Central Asia increased, shortage of food appeared as a serious problem. In the 11th century AD, Great Seljuk State ruling a great part of Central Asia and Near East encouraged the Turkish Oguz tribes to migrate into west (Anatolia and Azerbaijan) and south (Iran and Iraq) (Merçil, 2011). During the Anatolian Seljuk administration (12th century AD) search for pastures and movements of 
conquest were transformed into a systematic policy of settlement (Köprülü 1972). The Oguz tribes transferred their original Central Asian traditions of semi-nomadism into Anatolia, their new land.

The Oguz tribes that arrived in Anatolia named new places by using Central Asian names of mountains, gorges and rivers and they continued a semi-nomadic life between plateaus and surrounding mountains with approximately 100-200 km vertical oscillations. (Bakır, 1995, p. 33). In the Western Taurus Mountains, they stayed around the warm coastal zones (kışlak) in fall and winter and they moved to higher plateaus (yayla) in spring and summer. Moreover for fall and spring the semi-nomads stayed in a transitional zone called güzle (the place for staying in fall).

In history nomadic movements in Central Asia spanned quite long distances, had military character and led to serious political changes. In contrast nomadic culture of Anatolia had been regional and non-military. The Anatolian semi-nomadic cultures are built upon seasonal life cycle and reached today (Tanyeli, 1996, pp. 415-440). Nomadic lifestyle has always been in clash with central administrations (Yalman, 1993, pp. 38-40). Ottoman and Republican administrations tried to convert the nomads into sedentary citizens in order to increase agricultural production in a systematic manner (Türkay, 1979). As a result the nomadic cultures are in the phase of extinction.

In the Western Taurus region the tribes representing the semi-nomadic culture are generally called the "Yörüks". This name stands for the Oguz (Turcoman) tribes which have settled down in Anatolia. The Yörük tribes are concentrated around the provinces of Antalya, Mersin and Konya (Figure 1), which constitute a triangular area through the Western Taurus Mountains. The main cause for the concentration of the Yörüks in the Mediterranean Region is the local topography. In Antalya forests and green areas constitute 53,6\% of total land and the total amount of land usable by the semi-nomads makes 73,7 $\%$ of the total surface area of the province. This situation makes the region the center of semi-nomadic life in the country (Saraçoğlu, 1989).

Western Taurus region is differentiated from Inland Anatolia due to high rain rates and abundance of forests. With these topographical qualities the southern faces of Taurus Mountains provide "güzlek" and "yaylak" areas where Yörüks can stay during fall and summer, respectively. These lands are full of olive trees, pine, oak, beech, juniper and cedar trees (Yalman, 1993, p. 176). During the warm winter season, grass which grows around the coast recede as the weather becomes hot and the amount of rain decreases. Then the presence of grass moves up to higher altitudes (Saraçoğlu, 1989). The seminomads of the Taurus (Yörüks) move through the topography following this seasonal change of flora (Figure 1). The Yörük tribes who have goats depart from the pastures around the coast (kışlak / winter habitat) and move to the higher bushes (yaylak / plateau / summer habitat).

The life and production performance in the plateaus (yayla) makes it possible to be comfortable during the winter. If the animals are fed well in the plateaus then they will pass the winter comfortably. In addition milk, butter and cheese produced in the plateaus are sold in the neighboring markets by 
providing income for the winter (Seyirci, 2000, p. 5). Living in winter, fall and summer habitats are expressed with local terms like kışlamak (to live in places assigned for winter), güzlemek (to live in places assigned for fall) and yaylamak (to live in plateaus during the summer) (Yalman, 1993, p. 220). Every year the same places are used as kışlak and yaylak. The Yörüks move to the plateaus around April and May and go back to their winter settlements around October and November.

Figure 1. The Klşlak (Winter) - Yaylak (Summer) Routes and Names of the Yörük Tribes in the Western Taurus

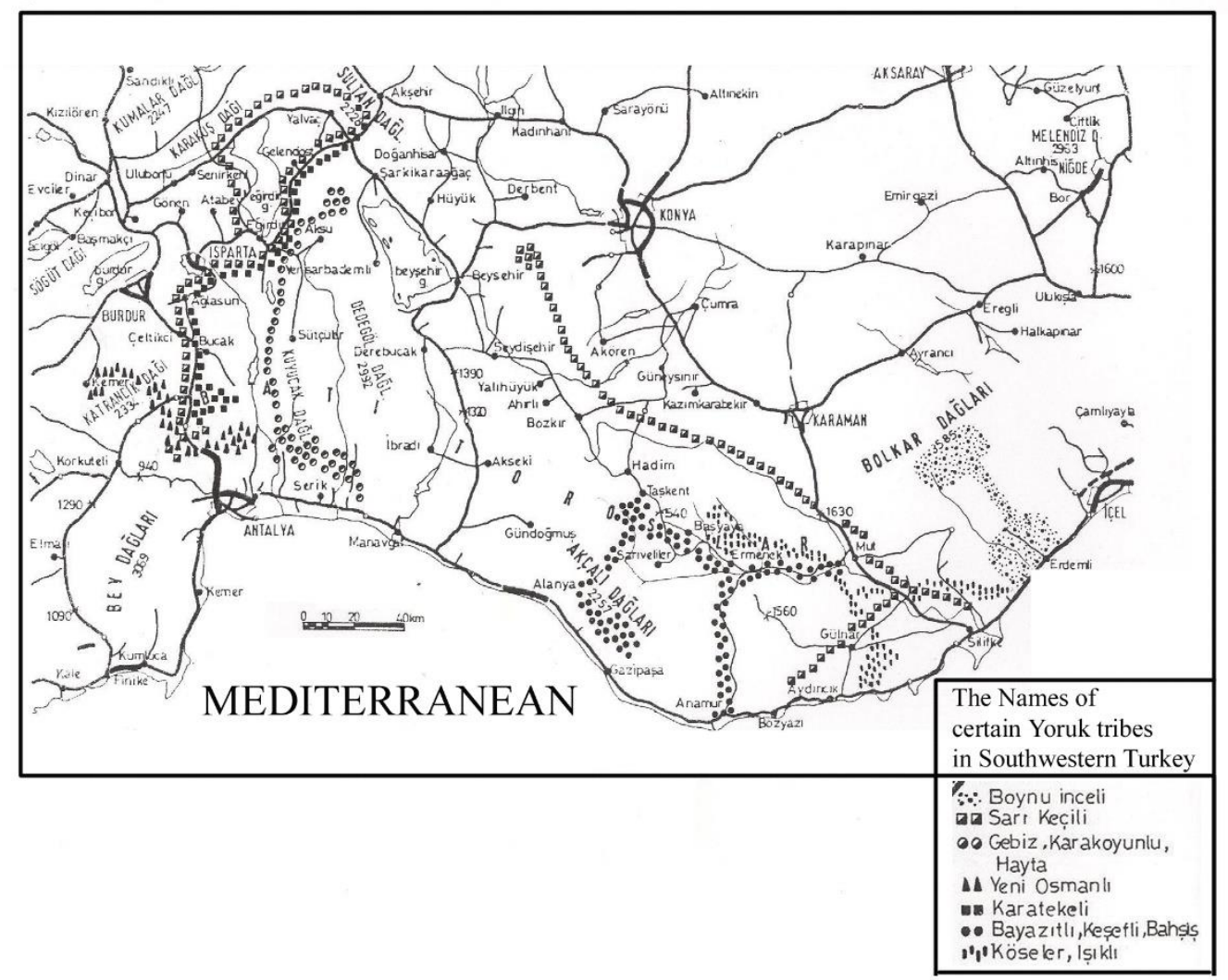

Source: Bakır 1995: 76

\section{Method: Spatial Analysis}

The semi-nomadic Turkish tribes have produced characteristic spatial configurations compatible with different cultural and geographical contexts they experienced (Yalman 1993: 53-57). Tents are indispensible components of this life style. When the Turkish tribes first arrived in Anatolia they faced Inland Anatolia which was similar to Central Asian climate and topography. Their sheep and traditional tents covered with felt were appropriate for these circumstances of the steppes (Figure 2). However as the Turks moved towards the coasts of Anatolia they discovered mountainous and rainy lands with new environmental problems. Therefore they started to breed goats instead of sheep because goats could be adapted to this environment. In addition they started to 
use "black tents" made up of goat's hair. This new material was resistant to rainwater (Figure 3) (Eröz 1991: 92).

Figure 2. Topak Ev (yurt): The Flexible Usage of Closed Surfaces and Spatial Configuration

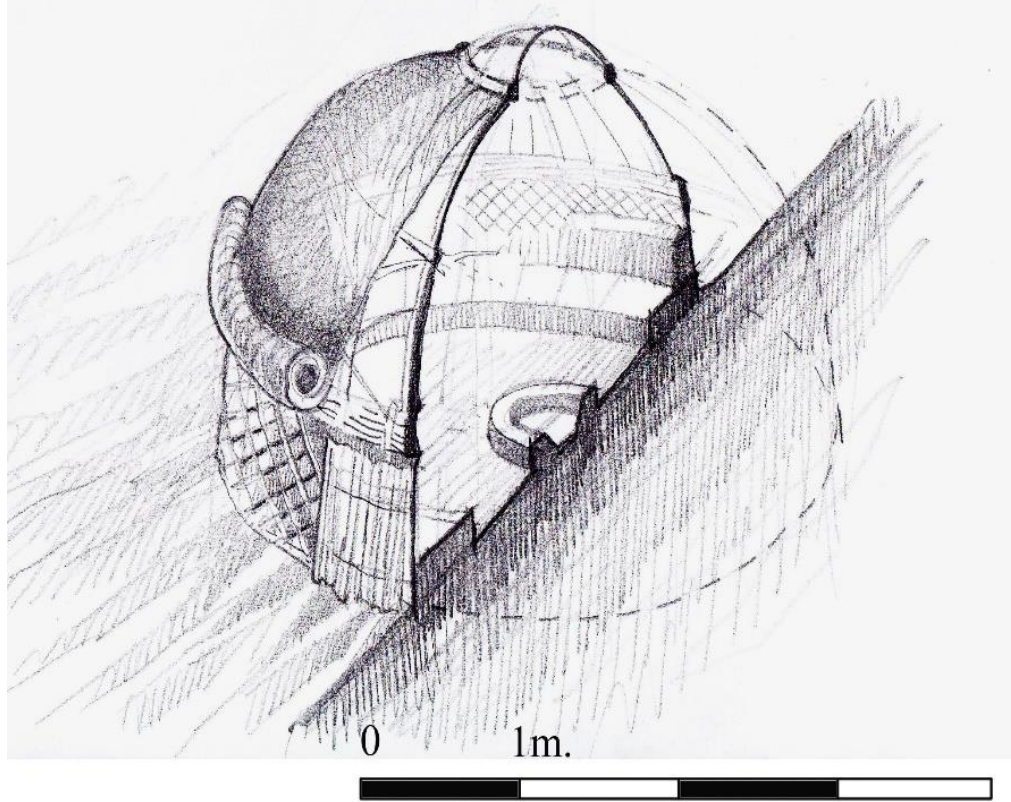

Source: Kavas 2013

Figure 3. The Semi-Closed Space Provided in Front of the Black Tent

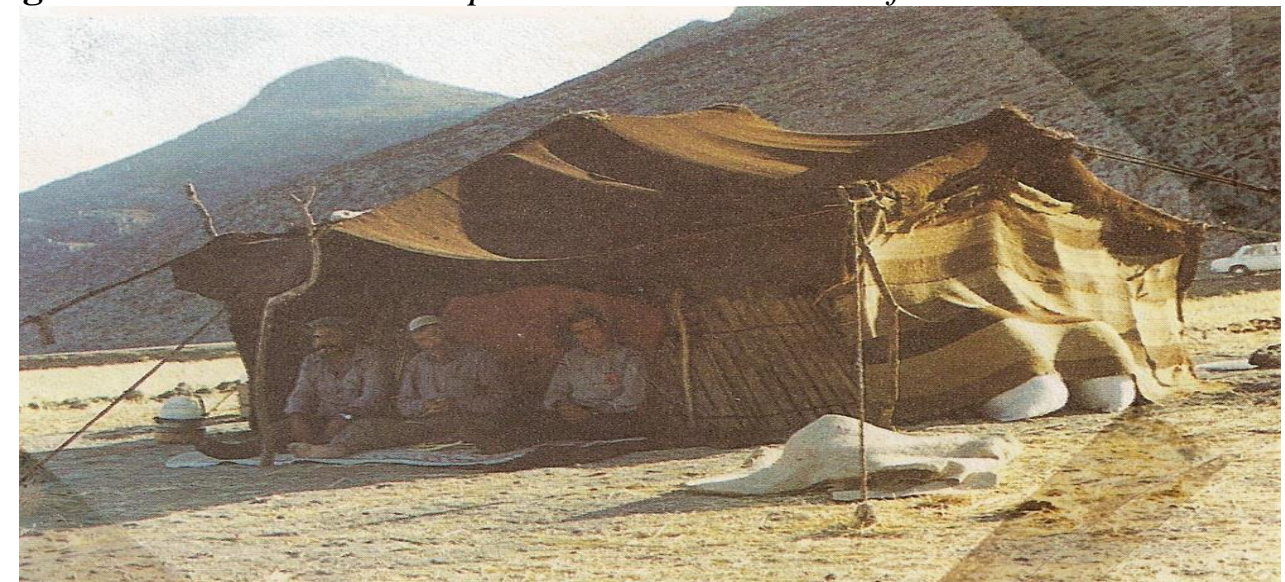

Source: Bakır 1995

The modular units (wings) with dimensions of $65-70 \mathrm{~cm}$ to $4-7 \mathrm{~m}$ constitute the tensile structural system of the "black tents". These units are connected by sewing and weaeved beams called "kolan" are formed. The shelter is carried by wooden posts with 230-250 cm heights (Bak1r 1995: 195). The horizontal balance is maintained by connecting these posts to eachother and to the earth by tensile ropes. In order to protect the interior space from 
undesirable external effects straw mesh is placed on the exterior surface of the tent structure. This mesh is supported by vertical wooden elements placed every $1-1.5 \mathrm{~m}$.

As a result of this construction process the dwelling space of the tent is defined by the haircloth covering the space from above, the posts and straw mesh on the façades and earth on the ground level (Kavas 2013: 239-243). With this configuration the tent is an easily-demountable, functionally-flexible dwelling with simple details (Figure 3,4). In this minimalistic spatial configuration, the equipment used in the interior space, such as kettles, containers, bags, matrices, looms etc. are very functional and few (Yalman, 1993, p. 257). The flexible and demountable elements provide high level of spatial mobility. Only the equipment which is indispensible for life is carried to the plateau while other heavy goods are left as custody in the winter place.

The interior space of the tent is approximately $3 \mathrm{~m} . \times 5-7 \mathrm{~m}$. This modestly dimensioned space is used with the principle of maximum efficiency. This space is used with a multi-functional understanding. The space satisfies all social and physical requirements such as storage, cooking, eating, sleeping, living and welcoming guests. The structural system not only solves physical problems but also satisfies social expectations.

Besides these tents, another form of semi-permenant structures called "alaçı, pür ev", "manar" and "çivrik" can be found in the plateaus. In addition, permenant vineyard dwellings are other components of life in the plateaus (Karpuz and Bakır 1990: 306). The vineyard dwellings are seasonal centers of agricultural production and they are also cool places for providing environmental comfort during the summer. Vineyards are known as places for grape production. However, in these places, almost evey kind of agricultural products are grown. The vineyard dwellings are used between April - May, when the product starts to grow, and September - October, when the products are collected from the fields. 
Figure 4. The Pattern of the Tents Owned by the Yeni Osmanll Tribe of the Yörüks during Summer in the Söbüce Plateau in Korkuteli, Antalya

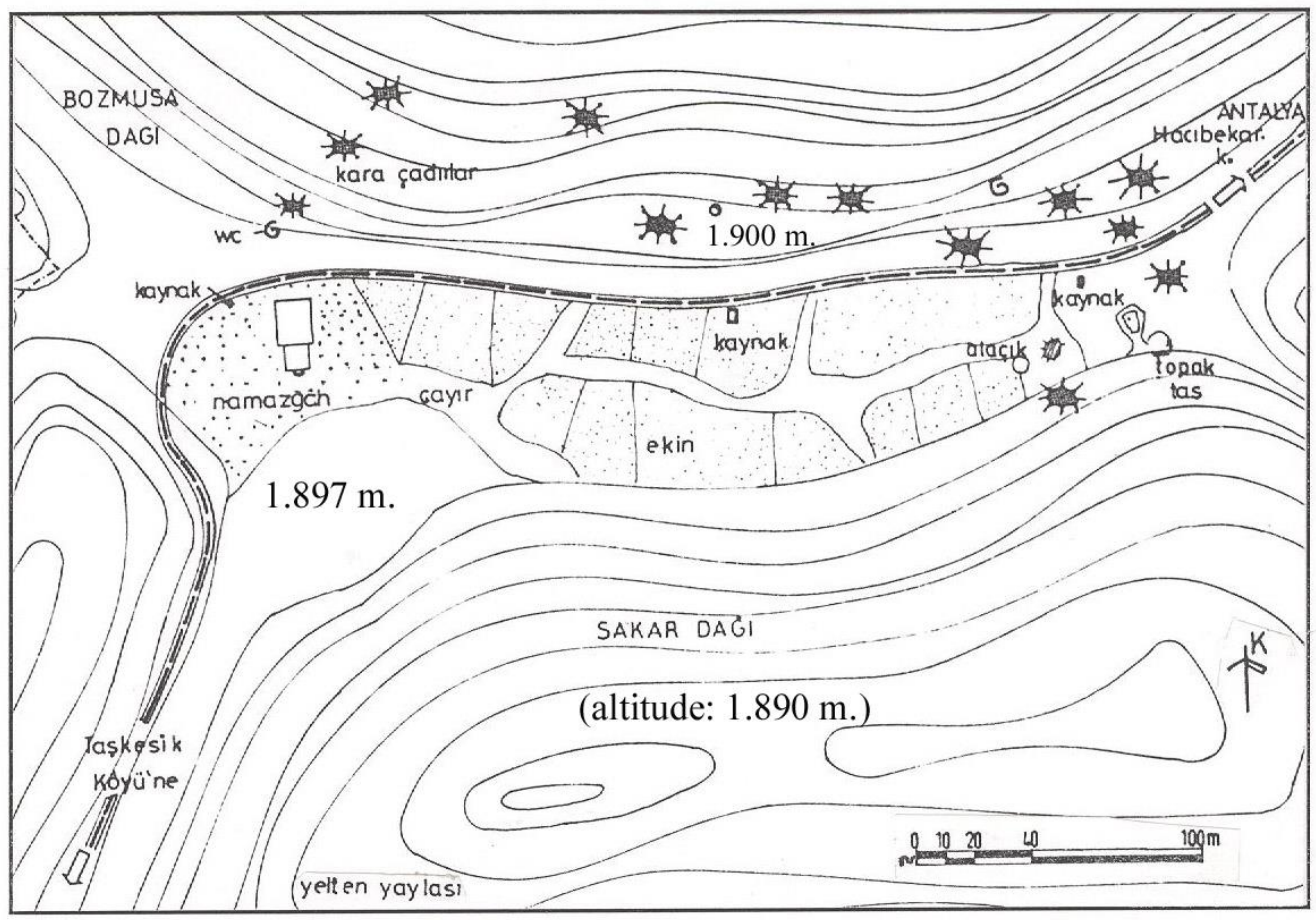

Source: Bakır 1995:82

The vineyard dwellings of the village of Ürünlü, situated in the Aksekiİbradı Basin on the Taurus Mountains illustrates the above mentioned dwelling type (Figures 5 and 6) (Kavas, 2009). The vineyard dwellings of Ürünlü are constructed on south-facing slopes and designed in order to use sunlight with maximum efficiency. There are abundant water resources (wells) around the vineyards so they can be used for systematic irrigation. As centers of agricultural production during the summer, these vineyard dwellings are basic elements supporting the sustainablility of a consistent life cycle in this difficult rocky topography. The winter settlement of Ürünlü is in the shape of a crescent facing southeast (Figure 5). There are around 150 dwellings in this zone. The winter settlement has a dense pattern. The crescent shaped settlement embraces a fertile green valley descending towards the river of Manavgat (ancient Melas River). In this valley there used to be many vineyard dwellings with a loose and dispersed settlement pattern (Figure 6). Each of these vineyard dwellings were assigned to a family's dwelling in the winter zone. Each family had one winter and one summer dwelling. In general, the distance between these two dwellings was between 1 and $2 \mathrm{~km}$. Therefore the kışlak (winter settlement) and yaylak (summer settlement) were embraced by the territory of the village (Figure 5). Ürünlü is a characteristic example wehere a semi-nomadic life pattern is sustained by permenant dwellings in kışlak and yaylak (Kavas 2009).

The Karabağlar Plateau in Muğla (southwestern Turkey) is another example where the plateau is situated in a level lower than the winter 
settlement. Therefore the cases of Ürünlü (Antalya) and Karabağlar (Muğla) indicate that the plateaus do not have to be on higher levels than the winter settlements. There can be microclimatic exceptions which provide environmental factors (fresh air, pastures, water resources, topographical isolation etc.) producing the plateau effect.

Figure 5. The Connection between the Winter and Summer Settlements in the Village of Ürünlü in Ibradl, Antalya. (The distance shown by the white line is $0.25 \mathrm{~km}$, eye altitude: $1.83 \mathrm{~km}$., elevation: $768 \mathrm{~m}$ )

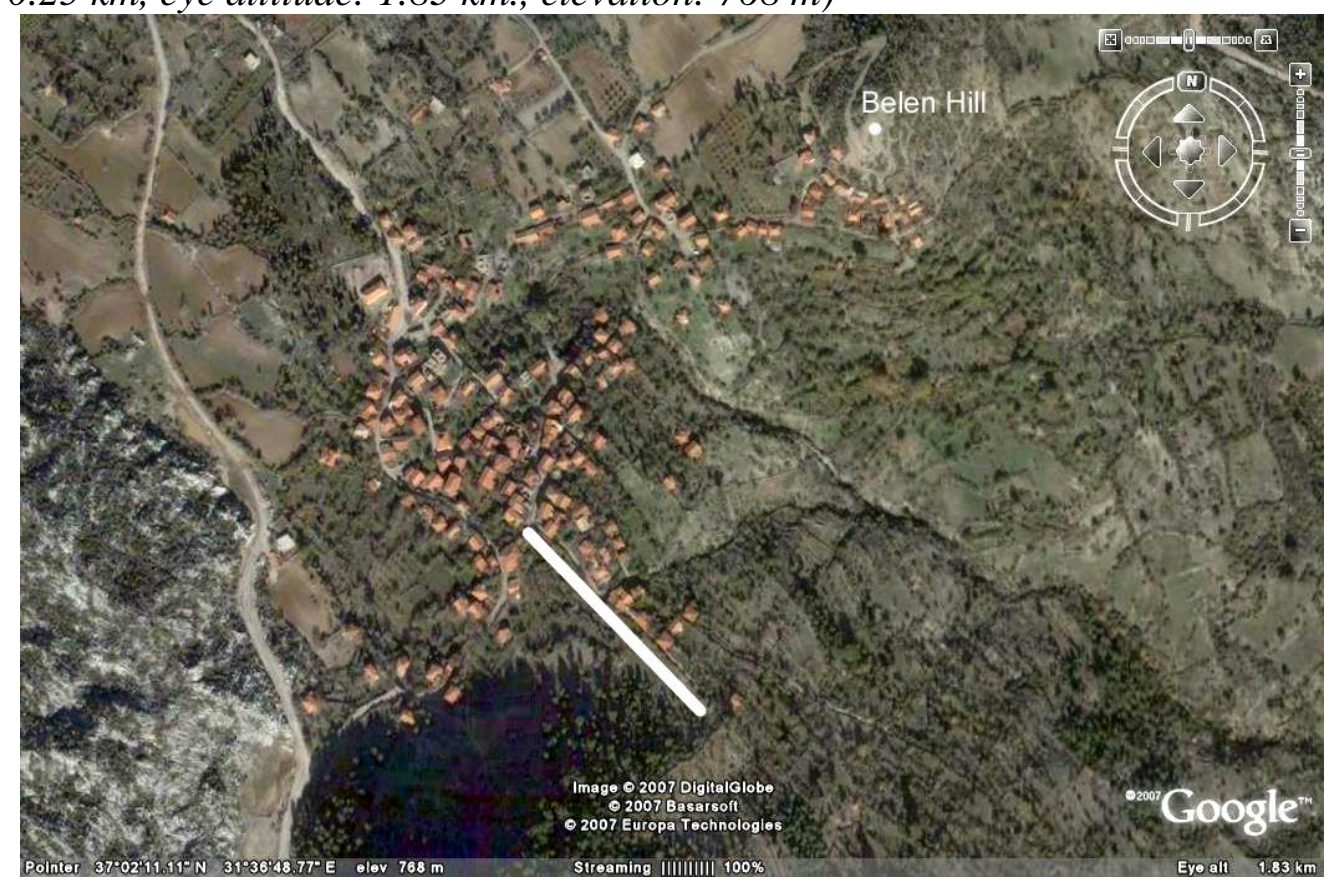

Source: Kavas 2009

Figure 6. The Spatial Configuration of the Traditional Vineyard Dwellings Enriched by the Semi-Closed Ayazlık Spaces in Ürünlü, Ibradı - Antalya

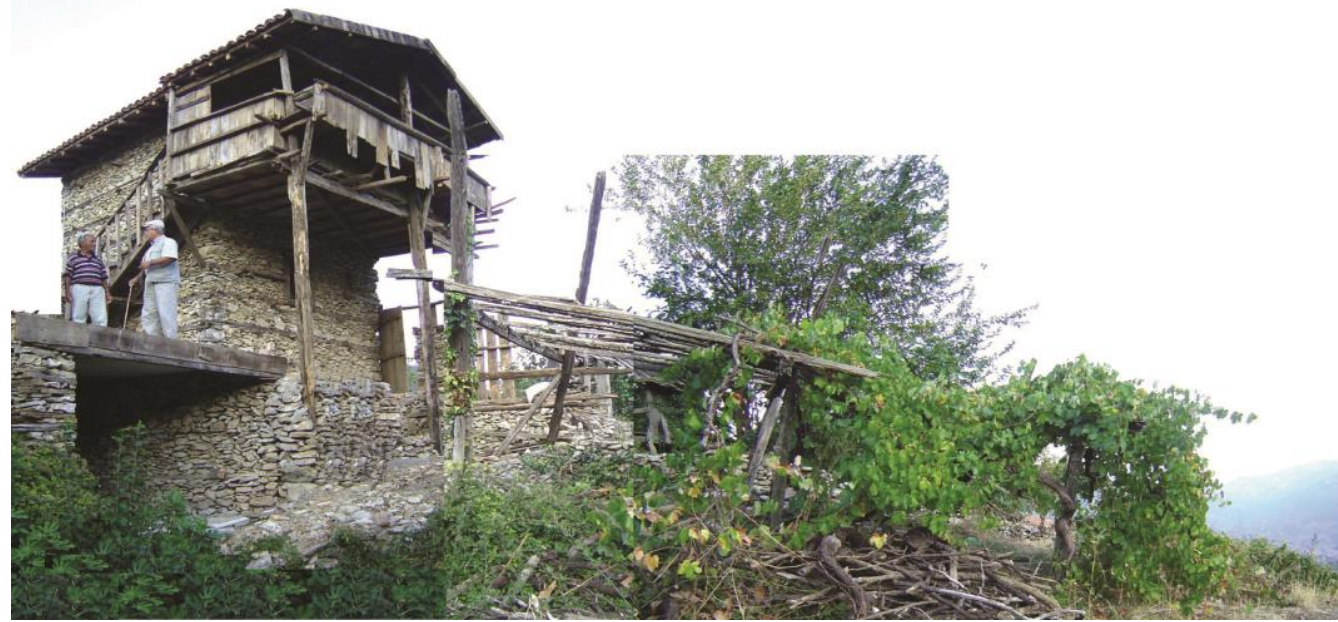

Source: Kavas 2009 


\section{Results}

The analysis of the research material through the proposed method and the historical development of semi-nomadism lead to the following results.

The semi-nomadic culture, in its traditional form, is still practiced by a very limited number of people living in the Western Taurus region. The history of nomadism is highly affected by the relations with sedentary state mechanisms. This life form was not approved by the late Ottoman administration because the state was not able to control freely moving seminomads. Therefore a settlement policy was imposed on this region. This situation continued during the Modern Turkish Republic.

After the 1950s, increasing amount of agricultural land, developing motorways and legal regulations for life in the forests challenged the seminomadic life and many Yörük tribes settled down in their "kışlak" (winter) places. Since these people were accustomed to seasonal mobility, they started to move to the plateaus with a few number of animals. Through agricultural advance, the Yörüks became more dependent on land and gradually lost their mobile skills.

Today, plateau life has become a limited recreational time needed for refreshment in the hot and humid summer. However, the Yörüks cannot leave their traditional life completely. They stay in their permenant dwellings in "kışlak" (winter) villages and move to plateaus where they also construct permenant dwellings instead of traditional black tents. Transportation between the kışlak and yaylak is no longer done in traditional methods but instead, motor vehicules are used.

Therefore the Yörük life has lost its traditional mobile, flexible and dynamic qualities and was transformed into oscilliation between two static points used in winter and summer. Since the movement between the seasonal points is isolated from environmental factors, the Yörüks lost their traditional abilities to cope with natural difficulties and their profound engagement with the environment.

\section{Discussion}

The traditional tents are partially preserved but they no longer constitute the majority of the dwelling units in the plateaus. The advantages of tents are their flexibility. They can be demounted for being taken into the permenant dwellings for protecting them from winter effects. When the Yörüks started to construct permenant buildings in the plateaus, at first they built vineyard dwellings with stone masonry and totally closed the former namazgah spaces (open air mosques) with a roof. In the next step, they started to construct reinforced concrete buildings disturbing the ecological harmony of the plateaus.

Even, some plateaus such as Sertavul and Gözne plateaus in Mersin were totally converted into permenant settlements. In the Western Taurus new 
permenant settlements have appeared. The names of these new settlements have the prefixes of "aşă̆ı" (lower) and "yukart" (upper). The settlements called "lower" (aşăğ) are former winter settlements (kışlak), while the settlements called "upper" (yukarl) are the former plateaus (yayla). For example, in Antalya the settlements of Aşağı Karaman and Yukarı Karaman illustrate how the former winter settlement and plateau of the Karaman territory were transformed into permenant settlements. A similar situation may be observed in the Aşağı Tırtar and Yukarı Tırtar villages of Mersin. In addition villages with completely same names also exist near the town of Yalvaç in Isparta.

As transportational and technological capabilities developed, the vineyard dwellings of the plateaus acquired different functions. The wooden vineyard dwellings of Bucak in Burdur, were converted into spaces for drying tobacco. Some of these structures were totally abondened and destroyed. Some of these vineyard dwellings were converted into primary dwellings of families when these dwellings were provided with electrical and meachanical networks (Karpuz ve Bakır 1990: 307).

Today people of different socio-economic profiles are interested in the plateaus with vacational purposes. As a result new reinforced concrete buildings with the function of "secondary houses" are constructed in the plateaus. "Secondary house" is a contemporary building type which is observed in the Mediterranean countries and other holiday locations. Buildings of low architectural quality are produced in holiday locations for only summer use and in winter these buildings are unused. Morevover these buildings violate the harmony of the environment. Therefore urban problems are transferred into plateaus by transforming these places into something other than plateaus (Figures 7, 8 and 9).

Figure 7. The Plateau of Söbüce in Korkuteli-Antalya (The Total Length of the Green Plateau Strip Is $2.50 \mathrm{~km}$ Eye Altitude: $4.00 \mathrm{~km}$, Elevation: $1.890 \mathrm{~m}$ )

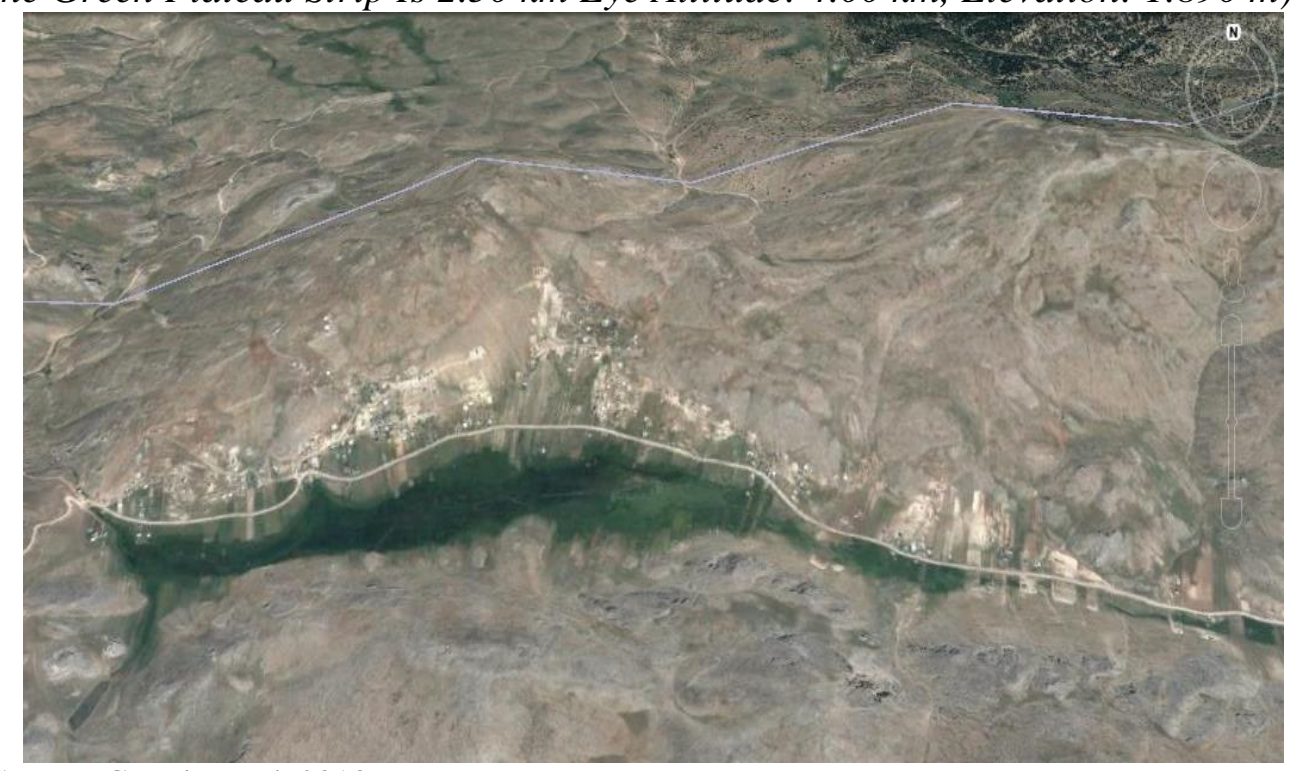

Source: Google Earth 2013 
Figure 8. The Plateau of Söbüce in Korkuteli - Antalya

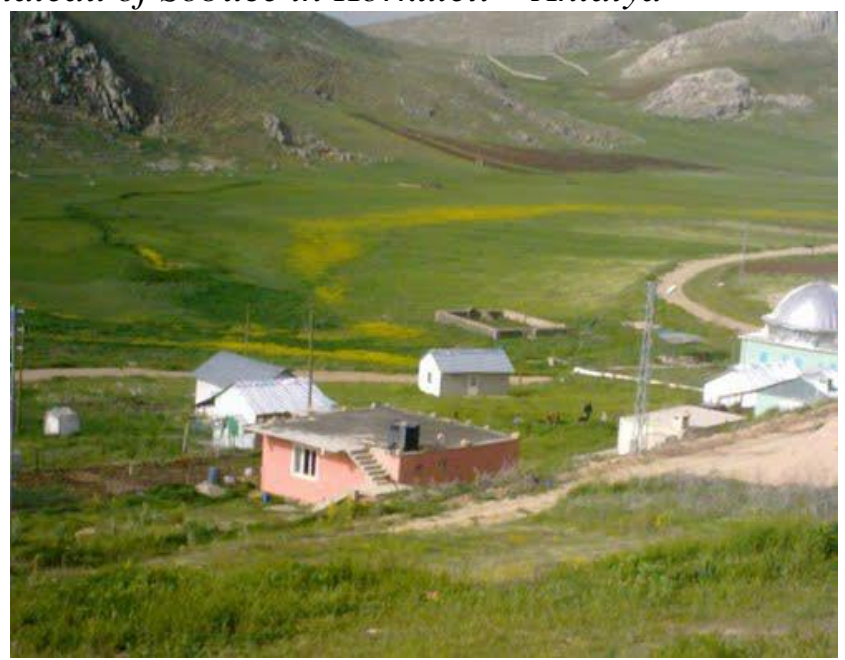

Source: Google Earth 2013

Figure 9. The Plateau of Abanoz in Anamur-Mersin

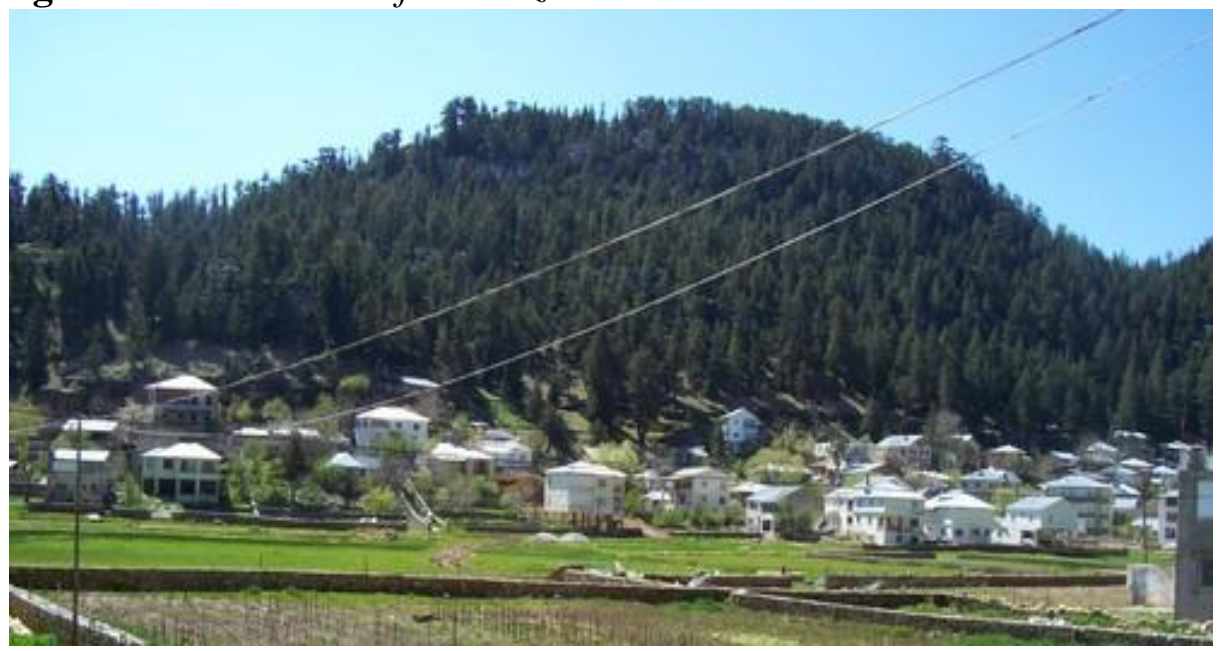

Source: Google Earth 2013

As a conclusion of this analysis the spatial principles given below can be regarded as the timeless values of plateau settlements and architecture:

In the traditional plateau settlements people did not settle down in the pasture locations and next to water resources like wells (Figure 4). This was a settlement strategy for protecting the natural resources, providing animals with healthy food and providing clean water for all the living creatures.

In architectural production natural, organic and recycled materials were used (Figures 2, 3 and 6). After buildings collapsed, materials with sufficient standards were reused in the construction of new buildings.

The design of space depended upon temporary and demountable spatial configurations and succession of closed, semi-closed and open spaces. These spatial principles could also be seen in the permenant traditional dwellings in the winter settlements and vineyards. 
Semi-closed spaces are important components of daily life either in tents or in permenant dwellings. These spaces face south or southeast. In the permenant dwellings these semi-closed parts are the external extensions of the common interior space called sofa. In the Akseki-İbradı Basin (Taurus Mountains, Antalya) these semi-closed spaces are called "ayazlık" (Figure 6) signifying "cool and comfortable space" (Kavas 2009).

Meanwhile, the contemporary spatial transformations taking place in the plateaus can be summarized as follows:

Today the plateaus are divided into small parcels on which dense building activity continues (Figure 9). This dense urban layout is at odds with the natural and traditional values of the plateaus. Contemporary building activity violates the traditional reverence towards nature and resources. Pastures and areas close to water resources are open to building activity.

Contemporaty non-organic and non-recyclable building materials challenge ecological balance of the plateaus.

For security reasons closed, isolated and hihgh rise buildings are constructed. This situation destroys the traditional close relation between man and earth. The traditional spatial patterns of semi-closed spaces are no longer active.

Recently there are studies for planning the settlement patterns in plateaus such as Sertavul (Mut, Mersin) and Feslikan (Antalya). These studies are due to the urgent need for planning the plateaus which are being converted into permenant settlements. In this way, it is expected that, in the near future many other plateaus will be planned and opened into construction acitivites.

Since the planning of the plateaus as settlements seem to be inevitable, planning strategies become very ciritical. In the planning process of the plateaus, the planners and architectural designers should pay great attention to the characteristic features of the land, cultural heritage values, and preservation of natural resources, ecological and cultural sustainability, traditional spatial patterns and settlement patterns. This planning process has to be reinforced by public consciousness regarding the historical, cultural and environmental value of the plateaus. The planners and new inhabitants should keep away from dense and high rise building production which seems to provide quick financial benefit but destroy environmental balance. Planning should be regarded as a tool for achieving these goals, which will provide benefits in the long run. To formulate the process and strategies of planning as such a tool, the history of the region should be analyzed in a sensible manner.

\section{References}

Bakır İ (1995) Batı Toroslarda Göçerlerin Yerleşme ve Mekân Sorunlarının Çözümü $\ddot{U} z e r i n e$ Bir Deneme. [An Inquiry into the Problems of Settlement and Space of the Nomads in the Western Taurus.] Unpublished Ph.D. Thesis. Selçuk University, Konya.

Braudel F (2002) The Mediterranean in the Ancient World. Wiltshire: Penguin Books. 
Chailand G, Berrett A (2004) Nomadic empires: from Mongolia to the Danube. New Brunswick, U.S.A.: Transaction.

Eröz M (1991) Yörükkler. [Yörüks / Nomads in Anatolia.] Türk Dünyası Araştırmaları Vakfi, İstanbul.

Karpuz H, ve Bakır İ (1990) Türkiye'de İkinci Konut olarak Yayla, Mezra ve Tatil Evleri. [The Turkish plateau, country and holiday residences as secondary dwellings.] In T.C. Başbakanlık Aile Araştırmaları Kurumu - Türkiye Aile Yıllığl, Ankara: $301-310$.

Kavas KR (2009). Environmental aesthetics of the rural architectural tradition in the mediterranean highlander settlement: the case study of Ürünlü. Unpublished Ph.D. Thesis. The Middle East Technical University Program of Architectural History, Ankara.

Kavas K R (2013) Mimariyi Dokumak: Anadolu- Batı Toros Göçerlerinde Çevre Kültür İlişkisi. ["Weaving" Architecture: the Relation between Nature and Culture in the Western Taurus Nomads of Anatolia.] In Bilig, Türk Dünyast Sosyal Bilimler Dergisi, (Sayı: 64 - Kış 2013) Ahmet Yesevi Üniversitesi Mütevelli Heyet Başkanlığı, Ankara: 231-258.

Köprülü MF (1972) Osmanlı İmparatorluğu'nun Kuruluşu . [The Establishment of the Ottoman Empire.] 2. Basım, Boznur Matbaası, Ankara.

Merçil E (2011) Müslüman Türk Devletleri Tarihi, [The History of the Muslim Turkish States.] Türk Tarih Kurumu Basımevi, Ankara.

Ögel B (1991) İslamiyetten Önce Türk Kültür Tarihi, [The Pre-Islamic Cultural History of the Turks.] 4. Bask1, Türk Tarih Kurumu Basımevi, Ankara.

Saraçoğlu H (1989) Akdeniz Bölgesi. [The Mediterranean Region] Milli Eğitim Bakanlığı Yayınları Öğretmen Kitapları Dizisi 175, İstanbul.

Seyirci M (2000) Batı Akdeniz Bölgesi Yörükleri. [The Nomads of the Western Mediterranean Region] DER Yayınları 262, İstanbul.

Tanyeli U (1996) Anadolu'da Bizans, Osmanlı Öncesi ve Osmanlı Dönemlerinde Yerleşme ve Barınma Düzeni [The Order of Settlement and Dwelling during the Byzantine, pre-Ottoman and Ottoman periods in Anatolia.]. In Tarihten Günümüze Anadolu'da Konut ve Yerleşme (T.C. Başbakanlık TOKI II. B.M. Insan Yerleşimleri - Habitat 1996 Konferansı Bildiriler ve Sergi Kitabi): 405471.

Totani G (2008) Indelebile nell'animo: l'Abruzzo dei Pastori. [Indelible Memory: the Shepherds' Abruzzi.] In Tratturi e Transumanza, Arte e Cultura. L'Aquila Italia: Associazione Deltensemble: 29-60.

Türkay C (1979) Başbakanlık Arşiv Belgelerine göre Osmanlı İmparatorluğu'nda Oymak, Aşiret ve Cemaatler [Tribes in the Ottoman Empire according to the Archives of the Turkish Prime Ministry]. Tercüman Kaynak Eserler, Seri: I, 1. Basım, İstanbul.

Yalman (Yalgin) AR (1993) Cenupta Türkmen Oymaklar1, Cilt I [The Southern Turkoman Tribes]. Kültür Bakanlığı / 256, Başvuru Kitapları Dizisi / 12, Ankara. 
